Para a realização dêsse estudo o Autor utilizou dois tipos de fontes. $O$ primeiro são os regimentos dos oficics mecânicos postos em vigor desde o fim do século XV e consolidados em 1572. A utilização dêsses regimentos foi feita em confronto com outros registros da época para ver qual a realidade que se poderia apreender dêsses estatutos. O segundo tipo de fontes são as estatísticas profissionais. As principais são a que se encontram no Livro de Lançamento e Serviço de 1565, que se pode considerar como um dos recenseamentos mais importantes de que se dispõe para uma cidade da Europa, a de Lisboa do século XVI. Foram utilizadas outras fontes estatísticas muito importantes para a mesma época, seja para Lisboa, seja para Coimbra, objetivando-se comparaçōes e críticas.

O estudo da estrutura social de Portugal, considerando-se o trabalho como ponto de partida, sua organização, sua divisão, é ralevante por duas razões principais: de um lado a historiografia portuguêsa se preocupou sobretudo com manifestaçōes exteriores do país na época dos descobrimentos; de outro, o interior do país e, principalmente, o mundo do trabalho ficaram pràticamente desconhecidos, devido ao preconceito contra o trabalho manual que esta historiografia inconscientemente incorporou.

A originalidade do tema e a conjugação de métodos de análise histórica e sociológica dão à obra impressionante vitalidade, aliando sincronia e diacronia, com preciosas informaçōes para os estudiosos das diferentes ciências sociais.

\title{
ADA NATAL RODRIGUES
}

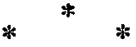

GALLE (Hubert). - La "famine du coton". Effets de la Guerre de Sécession sur l'industrie cotonière gantoise (1861-1865). Centre d'Histoire économique et sociale. Université Libre de Bruxelles. Institut de Sociologie. Parc Léopold. Bruxelles, 4.

Numerosas crises industriais chamaram a atenção dos historiadores. Bem poucas, entretanto, tiveram a gravidade desta que paralizou de 1861 a 1865 a industria do algodão.

Em 1861, quando eclodiu a Guerra de Secessão os Estados Unidos eram a principal fonte de abastecimento das fábricas que teciam o algodão; só êles produziam mais de três quartos dcs tecidos de algodão fabricados no mundo. 0 bloqueio do litoral sulista, a decisão dos Confederados de só entregar o seu algodão aos países que reconheciam o seu govêrno, privaram as praças manufatureiras da Europa da preciosa fibra. Durante atingidos pela "fome do algodão", muitos fabricantes cessaram de trabalhar; outros diminuiram consideràvelmente 0 ritmo de seu trabalho. Milhares de operários ficaram total ou parcialmente sem emprêgo.

o Autor, que centralizou o seu estudo em Gand, mostra como a situação foi piorando gradativamente nesse grande centro manufatureiro, a medida que se intensificava $o$ conflito americano. A redução das importaçōes de algodão, a alta vertiginosa dos preços da matéria prima, a venda a vil preço do fabricado, são minuciosamente analisados, da mesma maneira que o comportamento dos fàbricantes. Uma grande atenção foi prestada à especulação - tanto dos nego- 
ciantes como a dos industriais - aumentaram crtraordinàriamente os preços e tornou os mercados instáveis.

As rep:rcusões sociais da "fome do algodão" não foram negligenciadas. A miséria das famílias obreiras envolvidas pelo desemprêgo é profunda. Diferentes medidas foram postas em execução para remediar a situação. Graves desordens sociais são evitadas.

O trabalho repousa sôbre abundante documentaçāo inédita. Documentos con. servados no Stadsarchief de Gande foram compulsados, assim como numerosos maços de papéis relacionados com a crise, conservados no Ministério dos Assuntos Estrangeiros e nos Arquivos Gerais do Reino. O exame minucioso de todos êsses arquivos, o estudo dos jornais, a leitura de numerosos livros de ordem geral e particular, permitiram a êsse jovem historiador apresentar um volume cativante e que se lê com prazer. Gráficos bem executados facilitam a compreensão do texto de um bilo tamanho.

A obra de Hubert Galle interessará não sòmente os historiadores, mas todos aquêles que desejam conhecer e comprcender os problemas econômicos, financeiros e sociais contemporâneos.

E.S.P.



ERRATA DA REVISTA DE HISTÓRIA $-n^{\circ} 74$.

onde se lê leia-se

pág. 438

$\begin{array}{lll}\text { linhas } 20 \text { e } 32 & \text { roça } & \text { roca } \\ \text { pág. } 439 & \text { roça } & \text { roca } \\ \text { linha } 1 & \text { inconografia } & \text { iconografia } \\ \text { pág. } 438 & \text { Etátuas } & \text { Estátuas } \\ \text { última linha } & \text { lagrimais } & \text { lacrimais } \\ \text { pág. } 438 & & \\ \text { nota no } 7 & \text { às plásticas } & \text { às artes plásticas } \\ \text { nág. } 441 & \text { insipadora } & \text { inspiradora } \\ \text { linha } 16 & & \end{array}$

